\title{
Histological responses of the alternative or combined administrations of ACTH and GH to adrenal cortex
}

\author{
By
}

\section{Tetsuo ITO}

Dept. of Hist. and Embry. Tokyo Jikei-kai School of Med., Minato-ku, Tokyo

(Director : Prof. Fujio Yoshimura)

The hypophysectomized rats of Wistar strain receiving an operation in 60-90th postnatal day respectively were injected with ACTH and GH alternatively or in combination. The adrenal cortex of these animals was histologically examined in comparing it to that in control hypophysectomized rats and the results were as follows:

A decided conclusion was not obtained as to the changes in weight of adrenal cortex, since the number of experimental animals was small, and the value presented was complicated with the animal difference. But the organ body weight ratio shows that the adrenal gland surely decreases in weight by the hypophysectomy, but cannot be recovered from the reduction by means of the maintenance test of ACTH (2.5 mg/day for 7, 10 days) or $\mathrm{GH}$ (2 mg/day for 7 days), and of the repair test of ACTH (the same dose for 5 days) or ACTH and GH in combination (the same dose for 5 days), begun from the 6 th day after the removal. Therefore ACTH and GH would be uneffective to allow the animals to recover the loss of organ weight, so far as this admistration method is concerned.

However, it was informed in present research that the hormones are able to modify the histological changes induced by the hypophysectomy. The control hypophysectomized rats (7th day) provided the partially broadened zona glomerulosa in which the cells containing a lot of fat granules arrange fascicularly without a formation of glomerulum. The transitional zone became thicker, representing a layer of the package of nuclei. The cell-strands in zona fasciculata were irregular in general, slender, anastomosed one another and atrophic in some degree. Their cell-bodies were submitted to be rich in fat granules instead of proteinic stainable granules. The cortex cells at the vicinity of medulla surrounded by the multiplied connective tissue were usually flat in shape. The finding in the 10th day after the removal resembled in many respects that of the 7 th day, but tended to be shown as the more pronounced changes. When the hypophysectomized rats were administered for 7-10 days with ACTH, the zonation of adrenal cortex was precisely altered, although the whole thickness of it was not recovered. The elongation of cell fascicules in zona fasciculata presses the zona glomerulosa on the capsule. The disappearance of the transitional zone resulted in the mutual transformation between atrophic zona glomerulosa and broad zona fasciculata, where the former no longer consisted of independent glomeruli. The superficial area of adrenal cortex was scanty of fat granules, whereas full of stainable granules (stained with iron-hematoxylin). Despite the atrophic pattern and irregularity of fasciculata cell-strands was not restituted by the administration of ACTH, it was fairly demonstrated that the gross fused fat droplets decreased in number within the cellbodies, in addition the stainable granules increased. This fact may show that the improvement in the internal cell stracture fellow the replacement therapy. Also the connective tissue near the medulla_became thoroughly indistinct. As above mentioned, ACTH is expected to have the sweeping

Vol. 35 No. 12 
ability of some obstacles in intracellular hormone synthesis by the hypophysectomy, and at least the changes by ACTH was akin, beyond the recovery, to the pattern of elevation in function of cortical cells, as is seen in intact rats exposed by the stressful stimuli.

The repair test by ACTH showed the same improvement as by its maintenance test. Of course, the betterment may be restricted to zonation and cell internal structures in connection with the metabolic amelioration, but was not involved in the hyperplasia of cotical cells.

In the event of repeated injections of GH for 7 days (maintenance test) to the hypophysectomized rats, the symptom of the ablation is almost irrecoverable. The changes is not utterly reconcile with the findings of hypophysectomized untreated group, but usually provides the fascicular arrangement of zona glomerulosa whose superficial cells underlying the capsule are packed with the stainable granules, and whose profound areas contain numerous fat granules. Also GH administration alone could deprive of the connective tissue layer surrounding the medulla. Therefore it is enough to allow for us to make an assumption in the present cytological observation that the administration of $\mathrm{GH}$ alone is not always uneffective to the adrenal cortex, but engage in a certain stmulative actions.

The repeated injections of ACTH and GH in combination for 5 days (repair test) to the hypophysectomized rats made the remarkable improvement in the ablation symptom in the following respects : The hypertrophic action of zona glomerulosa was strongly inhibited; the cell-strands of zona fasciculata extend themselves to the capsule, beneath which is sometimes seen the immature glomerulum, where the consistuent cells were full of stainable granules instead of fat droplets; the deprivation of transitional zone resulted in the natural transformation of zona glomerulosa downwards up to zona fasciculata with the subsequent formation of the continuous elongated cell-strands. Despite the arrangement of fasciculata cell and the atrophic patterns were not sifficientiy recovered so much as by ACTH administration, it was a commonly characteristic to this event that the abundant stainable granules was associated with a lot of fat granules of the corresponding size within fasciculata cells, showing the excitable but stabilized pattern regarding the cellular metabolism. The combined administration may have an important links with the co-operated action to the adrenal cortex on reasons that the cell degeneration or disintergration near the medulla is most effectively sustained.

In summarized, we can furnish an information that, although the combined administration of ACTH and GH is unable to inhibit the reduction in cell number and volume, it may conduct to improve harmoniously the disfunction reflected to the cell distribution and internal structure, and rather put the cortex cells into a hyperfunctional state.

\section{Experimental Studies on the Influence of Endocrine Functions upon the Erythrocyte Respiration}

By

\section{Toshio MIGIHASHI}

Department of Medicine, Kyoto Pref. Univ. of Med. (Director : Prof. S. Tateishi, M.D.)

The author investigated the erythrocyte respiration in left ventricle blood of endocrine eviscerated rabbit and the effect of different hormone upon it. Oxygen consumption was measured by means of the direct Warburg's method, and coefficient of respiration was calculated.

Vol. 35 No. 12 


\title{
$\mathrm{ACTH}, \mathrm{GH}$ 単独及び同時投与による副腎 皮質の組織学的反応態度
}

\author{
東京慈恵会医科大学組織学教室（主任 : 吉村不二夫教授） \\ 伊東鐵男
}

緒 言

ACTH の検定には下垂体摘出動物を用いて副腎アスコルビン酸の回復度を指標として行う方法がある. ての検定法は Sayers, Sayers and Woodbury (1948) によつて行われて以来最す信頼すべき敏感な反応とし て一般に広く採用されている。既に充分明かな如く, AGTH は下垂体摘出動物のアスコルビン酸傎を充分に 回復させるに足りる力価をむつているのであるが，副腎の大きさや構造上の変化を回復させる力価は䫓著で はない，形態像を中心に判定する場合には，下垂体摘出後一定の期間を経て ACTH を投与するいわゆる repair test であ, 又術後ただちに ACTH を連続的に反復投与するいわゆる maintenance test であ何れす 反応度を数的に適確につかる得ない点が久点とされている. 我々の教室でも ACTH の副腎皮質細胞に対す る作用方式が細胞学的に検討されたが，横須賀（1959）は前揭の論文に於いて，ACTHは下垂体摘出ラ. トの副腎重量を回㣱させないにす拘らず, 細胞の内部構造及び細胞配列に於いては強く摘出症状を回復させ るどころか，反つて細胞が積極的に活動する事実を指”嫡した。

さて, Selye (1951，1950) は副腎皮質が ACTH 以外の trophic hormone によつても同時に支配されて いると考え, mineralocorticotrophin の存在を推定した。 それは $\mathrm{GH}$ 投与による諸藏器の組織学的所見が, DGA 大量投与による所园之類似している事, 及び GH は副腎皮質を肥大させ，且つ DGA 投与によつて 起る副腎皮質球状圈の萎縮を防止する事から，GH が球状圆を刺激し mineralocorticoid 法分泌させると共 に，組織の電解質代謝感受性を元めると晃做したととに基づいている，然し後に至つて（1950），彼自身下 垂体摘出所見が $\mathrm{GH}$ 投与によつて回復しないととから自説を訂正したととは周知の通りである. Stein 等 （1952）は副腎摘出ラットに GH を投与したが, 副腎の在, 不在が GH の生長促進作用の発現に対しては 無関係であるととを明かにし，球状層が GH の target organ であると見做さんとせる説には反対した.

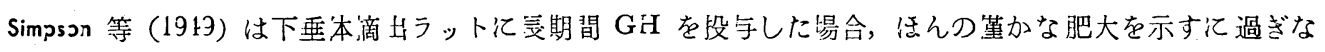
いととから，GH の副整皮質に対する直接作用は殆ど取るに足らないととを主張した。

さて, 最近 Deane 等 (1948) の副腎皮質 2 元論䎲対する反論が多数現われ（吉村の総説，1959参照）, 球 状層が下垂体の支配を離れた独立的層ではなく，やはり ACTH によつて調節されている層であることが明 加されれた. Wexler と Rinfret 等（1955）は 1 v.s.p. 以下又は以上の ACTH を下垂体摘出ラットにゲラチ ン溶液として投与して反応態度をしらべたとてろ，以下の量では球状層の脂肪顆粒が消失するが，以上の量 では殆ど消失しないととを認め, Venning 等 (1956) はヒトで ACTH が aldosterone 分泌を少し元めるて とを報告し，Lever (1956) は Na/K ratio を低下させる外的要因が加わつたり ACTH が投与されたラッ 卜の副腎球状層の変化を電子顕微鏡によつて検討し, mitochondria の osmiophilia, 脂肪顆粒, Golgi 装置 の状態が両者の條件で極めてよく似ていることから，ACTH が電解質代謝ホルモン形成に対する刺激効果 があるととを推定したのである。 その後, ACTH が示す球状層又は aldosterone 分泌付する調節作用は Muller 等 (1956)，Kovacs 等 (1957)，Nagy 等 (1957)，Maclean 等（1957）によつてあ盛んに主張され, 今日では 2 元論に対しても尚多くの支持者があるに拘らず， aldosterone 分泌に関しては球状襎細胞の主要 な役割を重視しながらも，ACTH は皮質全層の glucocorticoid 及び mineralocorticoid の双方を同時に調 節しているとの考えが抬頭するに至つた。 然るに，AGTH と GH との副腎皮質に対する協同的效果につ 
いては文献の上では当然予測できたにも拘らず，ての課題か浲祭に磪められたのは極く最近になつてからで あり，漸くRosenfeld 等 (1956) が分晟した牛の副腎皮質を用い，その medium の中に GH, ACTH を混 入させ, perfusion technique で aldosterone 分必検討を加えた。 その結果 GH 単独では Na retaining activity には何等著明な影響がなかつたが，ACTH を加えると明かな影響がる:られた。 Giroud 等 (1956) むラットの副粲を in vitro で incubate し, GH 単独では Na retaining activityには全く変化が起らな いが，ACTH はそれ自身であ軽度ではあるが確実な aldosterone 分必を增加せしめる作用のあることを指 摘した。一方 Bois と Selye (1957) は GH と thyroxine, ACTH と thyroxine との同時注射がラット副 腎を非常に肥大させるととに注意し，Lostroh とWoodward (1958), Losiroh（1958）は下垂体摘出ラットに $\alpha$-corticotrophin と GH とを単独及び同特注射（術後20日）したところ，同時注射が最も著明に回復した と述バた，又摘出後 5 日のラットを用いて，4 日間の注射実験を行い，その回復過程を検討し，同じ結論に 達している。

私の今回行つた実験は上の Lostroh の研究に刺激されて行われたあのであるが，教室の横須賀 (1959) が 報告した ACTH の副腎皮質細胞に対する作用方式に関する知見と比較しながら，GH と ACTH との協調 的作用を細胞学的に検討し, ACTH 単独投与との間に質的养異を求めようとしたのである

\section{実 験 方 法}

当教室で行つている一定の飼育環筧で自家媻殖せしめた Wistar 系雄性成熟ラット（生後60９0日）を濑 用した。第 1 群は下垂体摘出群で, 摘出後 7 日目（4例），10日目（3 例）のものである。第 2 群は下更 体摘法後 ACTH $2.5 \mathrm{mg}$ /日単独投与群で，下昰体摘出後の翌日より 7 日間投与（2例），10日間投与!( 2

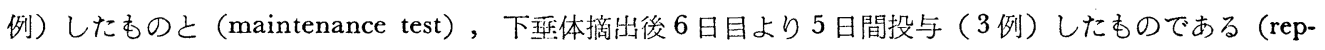
air test). 第 3 群は下垂体摘出後 $\mathrm{GH} 1 \mathrm{mg} /$ 日単独投与群で, 下垂体摘出の翌日より 7 日間投与 ( 6 例) した。第 4 群は下垂体摘出後 6 日目より $\mathrm{ACTH} 2.5 \mathrm{mg} /$ 日 と $\mathrm{GH} 2 \mathrm{mg} /$ 日とを 5 日間同時投与（ 4 例）し たあのである (repair test).

動物は何れむ $18 \sim 22^{\circ} \mathrm{C}$ の恒温室内に飼育し, 出来得る限り外部的ストレスが加わら品様に注意した. 食话 は教室所定の混合食（ふすま6, 乙如 6, 細麦 2, 魚粉 1) である. 用いたホルモンは Armour のACTHAR (Lot No. R. 68305, P. 46203), Armour の SOMAR-A (Lot No. R. 285128, R. 50109) である. ACTH. GH は水溶波で1 日 1 回背部皮下注射を行つたのであるが，その持続效果は充分とは云えない，理 想的には perfusion 又は suspension の形で行うべきでその点今後の研究でやり直したいと思つている. 又 今回用いたホルモンの 1 回投与量も少々多すぎたきらいがある。 Lostroh (1958) は ACTHも GH も suspension の 形で 0.050 0.250 mg/rat 与えている. 1 単位以上と以下では或る程度反応態度が異なると 云う意見 (Wexler，Rinfret 等 (1955)) あある。 又2単位/日4日，1単位/日11日間では corticosteroid 生 壁は正常ラットに於いて促進されないが，16〜54 単位では36時間以内に急激に增加するてとも知られてい るが (Holzbauer とVogt (1957))，私は今回は $2.5 \mathrm{mg} /$ 日 で注射を施行した。

所晃

\section{重量変化 :}

使用した動物の体重及び副篮重量の变化は表 1 亿示す通りであるが，例数の僅少或は動物の㮯体美がから み合つて実験值と予想される理論值と大分異なつている.

第 1 群の下瑟体摘出群では諸家の述べる如く副腎重量は下重体欠落により減少している，第 2 群の下垂体 摘出 ACTH 投与群では 7 日間投与と10日間投与とでは後者の方が副腎重量は大で，ACTH の効果とあ考 えられるが，その真偽のほどは明睹でない，又下垂体摘出後6日目より ACTH を5 日間投与したあのでは 実験值から見れば，副腎重量の増加は多んどなく第 1 群の下垂体摘出 7 及び10日目のものと変りない. 第 3 
Table 1. Effect of ACTH and GH on the adrenal organ weight of hypophysectomized rats.

\begin{tabular}{|c|c|c|c|c|c|c|c|c|c|}
\hline Groups & $\begin{array}{c}\text { No. of } \\
\text { rat }\end{array}$ & $\begin{array}{l}\text { Days after } \\
\text { hypophy- } \\
\text { sectomy }\end{array}$ & $\begin{array}{l}\text { Admini- } \\
\text { stration }\end{array}$ & $\begin{array}{l}\text { Daily } \\
\text { dose } \\
(m g)\end{array}$ & $\begin{array}{l}\text { Injection } \\
\text { periods } \\
\text { (days) }\end{array}$ & $\begin{array}{c}\text { Body } \\
\text { weight } \\
\text { (gm) }\end{array}$ & $\begin{array}{c}\text { Adrenal } \\
\text { weight } \\
\text { (mg) }\end{array}$ & $\begin{array}{l}\text { Organ } \\
\text { B.W. } \\
\text { ratio }\end{array}$ & Average \\
\hline \multirow[t]{2}{*}{ I } & 4 & 7 & none & & & $\begin{array}{ll}\text { a. } & 127 \\
\text { b. } & 108 \\
\text { c. } & 127 \\
\text { d. } & 120\end{array}$ & $\begin{array}{l}24 \\
17 \\
17 \\
15\end{array}$ & $\begin{array}{l}0.018 \\
0.015 \\
0.013 \\
0.012\end{array}$ & 0.0145 \\
\hline & 3 & 10 & none & & & $\begin{array}{ll}\text { a. } & 120 \\
\text { b. } & 123 \\
\text { c. } & 118\end{array}$ & $\begin{array}{l}17 \\
18 \\
18\end{array}$ & $\begin{array}{l}0.014 \\
0.014 \\
0.015\end{array}$ & 0.0143 \\
\hline \multirow{3}{*}{ II } & 2 & 7 & ACTH & 2.5 & 7 & $\begin{array}{l}\text { a. } 140 \\
\text { b. } 85\end{array}$ & $\begin{array}{l}24 \\
14\end{array}$ & $\begin{array}{l}0.017 \\
0.016\end{array}$ & 0.0165 \\
\hline & 2 & 10 & ACTH & 2.5 & 10 & $\begin{array}{l}\text { a. } 110 \\
\text { b. } 118\end{array}$ & $\begin{array}{l}24 \\
23\end{array}$ & $\begin{array}{l}0.021 \\
0.019\end{array}$ & 0.0200 \\
\hline & 3 & 10 & ACTH & 2.5 & 5 & $\begin{array}{lr}\text { a. } & 115 \\
\text { b. } & 115 \\
\text { c. } & 95\end{array}$ & $\begin{array}{l}18 \\
14 \\
16\end{array}$ & $\begin{array}{l}0.015 \\
0.011 \\
0.016\end{array}$ & 0.0140 \\
\hline III & 6 & 7 & $\mathrm{GH}$ & 1 & 7 & $\begin{array}{l}\text { a. } 120 \\
\text { b. } 130 \\
\text { c. } 130 \\
\text { d. } 115 \\
\text { e. } 118 \\
\text { f. } 108\end{array}$ & $\begin{array}{l}20 \\
17 \\
18 \\
15 \\
24 \\
18\end{array}$ & $\begin{array}{l}0.016 \\
0.013 \\
0.013 \\
0.013 \\
0.011 \\
0.016\end{array}$ & 0.0136 \\
\hline IV & 4 & 10 & $\begin{array}{c}\mathrm{ACTH} \\
\mathrm{GH}\end{array}$ & $\begin{array}{c}2.5 \\
2\end{array}$ & 5 & $\begin{array}{ll}\text { a. } & 150 \\
\text { b. } & 128 \\
\text { c. } & 135 \\
\text { d. } & 135\end{array}$ & $\begin{array}{l}27 \\
15 \\
14 \\
16\end{array}$ & $\begin{array}{l}0.018 \\
0.011 \\
0.010 \\
0.011\end{array}$ & 0.0125 \\
\hline
\end{tabular}

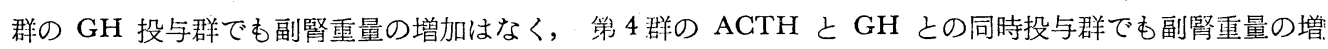
加は全くないのである。即ち重量的関係から総体的に眺如佫，ACTH を下垂体摘出後翌日より長期にわ たり持続的に投与したならば或は重量の回復が或る程度起つて来るととも可能の様に思すれる．然るに一定 期間を嘪いた後に投与した場合では，GH は勿諭，ACTH でも副腎重量の回復は殆ど認められなかつた。

\section{組織学的所見 :}

\section{1) 下垂体摘出群 :}

下垂体摘出ラットの副腎皮質の組職像については既に横須賀（1958）が発表した，今回の観察も大体に於 いてそれと一致した，術後７日群では球状層は幅をましている（図 1）。しかし10日以後のものと比較すれ ば未だそんなに厚くはなく，正常ラットのそれに近い場所も残つている．球状層には豊富な脂肪顆粒が充満 し，Zona spongiosa の観を呈している（図 2）。下垂体摘出後10日以上の経過の如く，球状層はまだ典型 的な束状配列を示すととはないが，その傾向が多少とあ現われて来る．可染性顆粒は少いので，乙の点で球 状層とそれ以下の層とが明瞭に区別される。被膜下には幼若な皮啠細胞は見られず一様に成熟度の進んだ細 
胞ばかりである。移行首は幅を增し，核の密集帯となり，配列は全く不規則で，細胞の境界は不明蹽であつ て（図 1，2），むはや正常雄対照ラットに見られるが如き扁平な細胞ではないようである．胞体には常に 脂肪顆粒を有しないか，或はあつても少く，その代り多くの可染性顆粒を含んでおり，著しく暗調である. 束状層では細胞の配列は乱れて，その細胞索は細く，束状配列は不完全となり互に吻合している。細胞は多 少とも萎縮性となり，境界は明瞭を欠いている（図 3 ）。胞体内には脂肪顆粒が豊富に存在するが，一方可 染性顆粒は少ない，脂肪顆粒の大きさは球状首におけるそれより小さく，又大小不均等である．核には染色 性顆䊀が多く，又濃縮に陷ることもある，取り立てて網状層と云える場所はなく，束状層全体がある意味で は網状配列をしていると云えないことはない，䯣質近くでは細胞は扁平となり，周辺に結合織の増生が見ら れる。

下垂体摘出10日後の副腎皮質は 7 日後の所兌之略々等しく，唯上記摘出症状が除々に増強されて行く，即

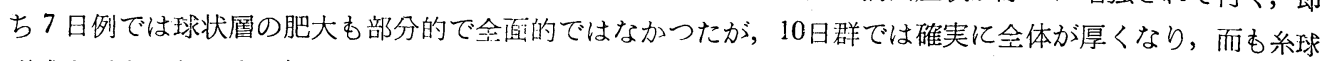
形成と云うよりは蜜万細胞は柱状配列を是する場合が多い（圆4）。然し細胞の境界は正常ラット之同栚に 不焦明であつて胞体は粗大な脂肪顆粒で充满される，7日例ではまだ浅首に比輘的小さい脂肪顆粒が出現し ている部分があつたが，10日目では凡て粗大な脂肪顆粒ばかりになつている，10日後では束状層全体の厚さ

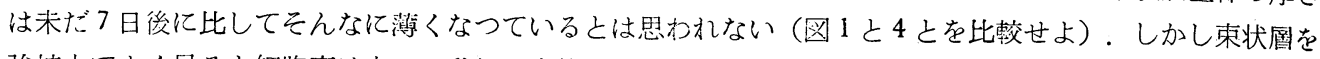

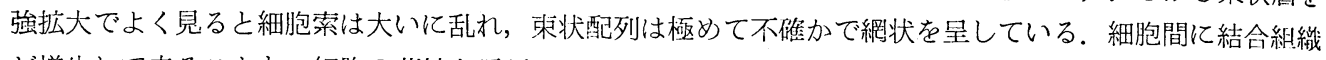

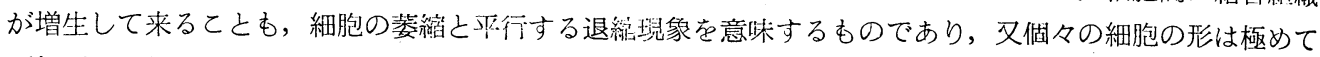
不規則であり，その内に豐富な脂肪顆粒の心かに可染性顆粒む現われて来る．束状層深部では細胞の配列は

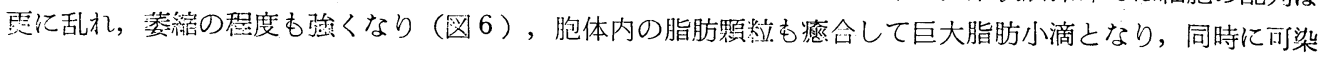

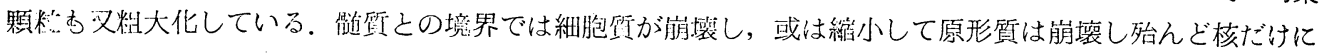

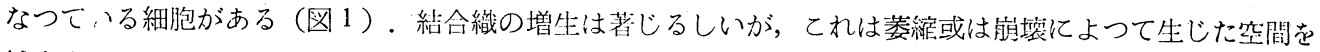
補充するための反応であろうと思われる。

2) 下童体摘出 ACTH 単注投与群:

下重体摘出後翌日より ACTH $2.5 \mathrm{mg} /$ 日を 7 日間尰続投与した場合 (maintenance test) には, 図 1, 図

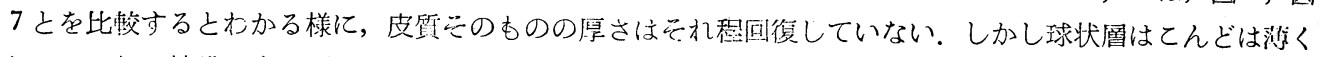

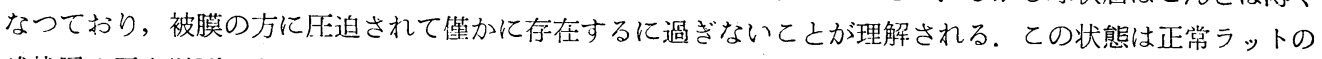
球状圈の厚さ以下である。而も図1では粗大な脂肪顆粒が允满し明調であるが，図7では暗調を呈してい

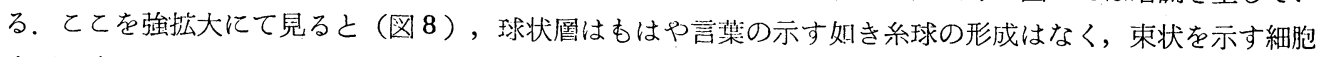
索が上万に登つている。中には被膜直下で反転して dome を形成していることもある。細胞には豊富な可 染性顆粒と mitochondria が充満するが，脂肪顆粒は極めて乏しく，深風に僅かにみとめられるに過ざない．

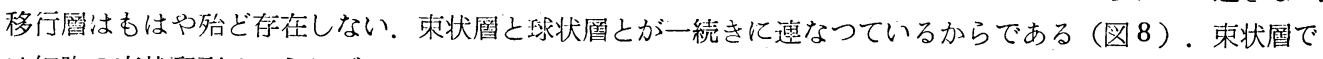
は細胞の束状配列はみられず，やはり下垂体摘出群之同様不規則な配列を示し，又個々の細胞も菱縮性であ り，細胞の境界がわかりにくい，しかし反面胞体内には可染性顆粒が多数出現しており，脂肪顆粒は少ない． 下垂体摘出によつて細胞か涹縮性変化传るが，乙れは ACTH の投与によつて防止することは出来ないけ れども, 紐胞の内部構造は或る程度積極化することは明かである. 例えば可染性顆粒が増加するととは動物 がストレスに曝された場合に常に起り得る所見であり, 又移行㒸の消失, 球状首の縮少並びに束状配列の出 現等は何れあ副腎皮質に於ける蟣能九進像を示すすのである (Yoshimura 1954 参照). 䯣質の近くに現われ た結合組織の増生む ACTH の投与によつて消失することもその理由の一つである.

ACTH 2.5mg/日を10日間投与した場合では球状关の圧迫縮小は 7 日群より更に大となる（図 9 )。しか し束状㜿の幅は前と同棁にせまく，沿ど回復していない，又移行風は全く消失し，束状層の細胞索はそのま ま上方に向い被膜まで達し皮質表面は束状配列する傾向が強く, 時にいわゆるZona arcuata の形態を呈 するととあある．従つてあはや何処が球状層仙なついるかが不明であつて，てのととはストレスに曝露さ れた時に現われる副腎皮質の機能九進像と似ているのである。束状㐿の萎縮，短縮は10日間の注射によつて 
尚改善されはしていないけれぞも, 束状圈細胞には可染性顆粒が前と同様に多く, やはりこれも代謝面では 副腎皮質の積極性を物語る。10日間投与群では束状症の深層或は㵦質の近くでも, 細胞内に殆ど粗大な脂肪 顆粒が現われないで，小さい弱染性顆粒で満されている．又束状層及び網状層では類洞腔は拡張し充血して

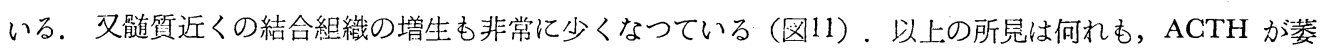
繀に陥つた細胞を full に回転して幾分なりとあ分泌機能を履行させているととを意味する像ではないかと 考えられる.

次に下垂体摘出後 6 日を経てから ACTH を 5 日間投与した場合 (repair test) では，術後長い間隔をお いたにも拘わらず下垂体摘出の症状は大いに俥減され，やはり球状層は下垂体摘出群の様に厚くはなく，若 干とあ回復の街候を示し，幅を狭めていた（図12）。移行首は一度肥大したものが再び消失している。こし

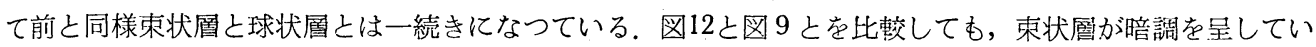
る程度か強い以外は殆ど同じ所見であつて，ACTH の完全な欠落状態が 6 日間を経過して出ていてもての 量の ACTH によつて充分によく回復させ得るととがわかる。球状層を焾桩大でるるると, maintenance test の場合の様に細長い束状を呈するととはなく，かなり太い細胞索を形成する，又 repair test では細胞に強 染性顆粒を極めて豊富に充满させるととが特徴で（図13），やはりこてには脂肪顆粒が少いのである，次に 束状風細胞の配列の乱れはよく修復され maintenance test よりす等ろ repair test の方がやや美しい配列 を示している. 個々の細胞はそれ亿す拘らずやはり萎縮しており, 依然として正常群の如き飽满な原形質を

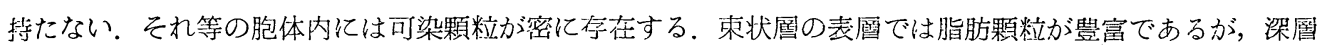
では次第に減少して可染性顆粒に取つて代る。しかし完全に消失することはなくかなり残つている。乙のて とが maintenance test と異なる点である。束状層深層ではやはり充血像があり，䯣質の近くに出現してい た結合組織の增生が起らない，乙れらの事柄はやはり外因的に与えられた ACTH によつて副繁皮質は自己 の細胞を積極的に働かせホルモンの合成を行つているかの如き像であり, maintenance test 孞どではない にしてあ，ACTH が代謝面において極めて有効に作用したてとを物語つているようである.

3) 下垂体摘出, GH 単独投与群 :

下垂体摘出後翌日より GH1 mg/日 7 日間迶続投与したすのでは图15亿示す如くやはり下重体摘洁の症状 は上く回復しない. 皮欣全圆の厚さは低然として薄いととは ACTH 投与と同じである, ACTH と GH との单

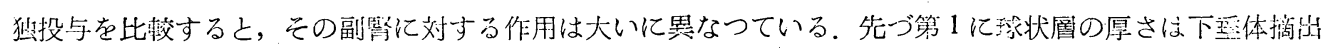
のレベルと佲ど同じであるととである。下垂体摘出時に艺うであつた圳く球状首の細胞は束状に配列し，被

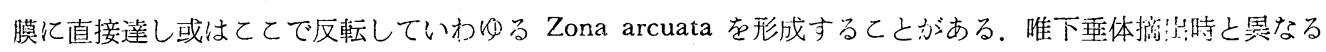

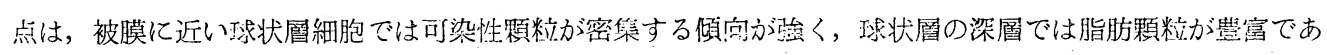

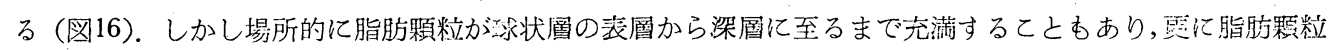

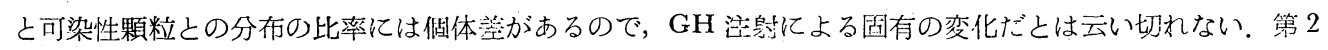

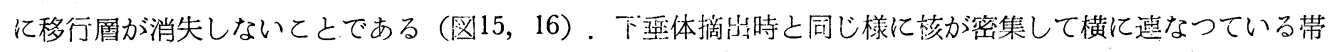
として認められる．ての細胞の踥界は不明暸であるが核の割㲸細胞の胞体は小さく一定の区劃内に互にひし めき合つているような感じをうけ，胞体结何れも強染性の微細な顆粒と， mitochondria を入れるが，脂肪 顆粒む時折含んでいるととが明かである（図16）。第 3 は束状粕細胞に脂肪顆粒がやはり大分残つているが，

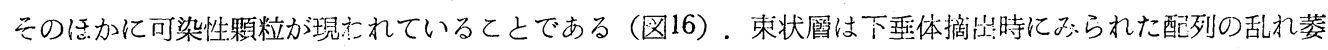
縮等は完全に残つており，ACTH と同様 GH あ萎綰性変化を回復することはできない，又㑬々の細胞の 内部構造では ACTH の様に可染性:顆粒を增加させるととは不能で, とくに束状層の表周では Zona spon-

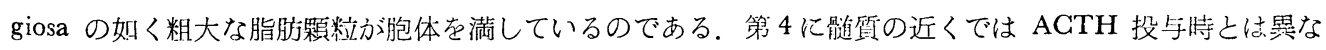

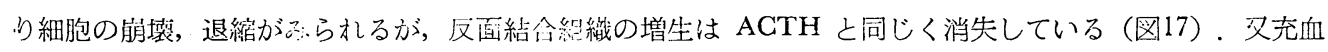

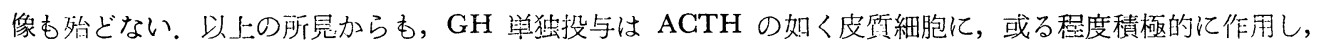
やはり代謝面で恐らくでく整度の改善をむたらすすのであるが，この积度は問題になら留程後者に劣り，之 くに球状層，移行風を狭ばめ又消失させる力はない，さりとて，下垔体摘出症状と全然同じであるかと云う 
とそうではなく，或る程度改善させるととは確かである。乙れは GH が多少の ACTH を contaminate しているか，或いは GH 自身に多少は向副腎皮質作用があるか何れかである.

\section{4) 下垂体摘出, $\mathrm{ACTH} \subset \mathrm{GH}$ の同時投与群：}

下俥体摘出後 6 日目より ACTH $2.5 \mathrm{mg}$ /日 及び $\mathrm{GH} 2 \mathrm{mg} /$ 日 とを 5 日間にわたり漙続的に同時に投与し た群では図18に示す如く摘出症状の著しい改善がある. 図12に示す如くACTH 2.5mg/日 の repair test に

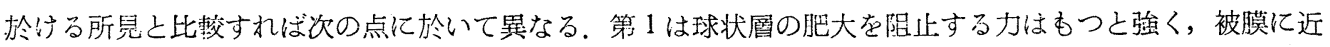
く汪迫されている球状㬝は細い而も短い束状配列を示すことが特徴であり，胞体内には可染性顆粒が充満し，

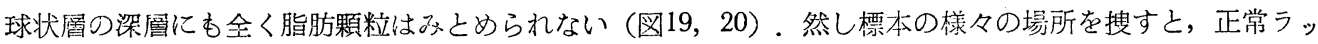
トに岁らられる様な糸球形成が多少見られ，共通の被膜でつつまれた境界不明の細胞集団が見えて来る，尚又 被膜直下には幼若な孤立性皮質細胞が出現し，乙れが2〜3個の小集団をなしていることがある。この様な 㭃若細胞には可染性顆粒が充満するが，脂肪の合成は殆ど行すれていない，可染性顆粒は浅層に至るはど增

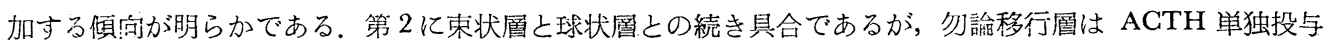
時の如く完全に消失しており, 両層はじ加㑑接している。図19に見られる如く両層の細胞索は非断続的で

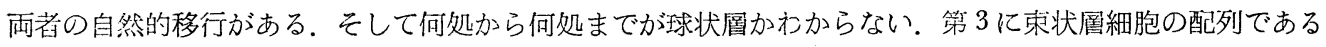
が，ACTH とGH との投与によつてずつと美しい束状配列を示す様になる（図19と図13とを比較せよ）.

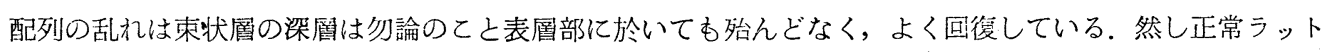

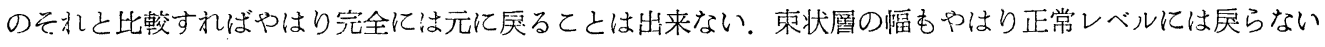
のである。第 4 亿束状層細胞の内部構造であるが, ACTH 投与之同じように脂肪顆粒は減つており, 可染 顆粒が浚数存在するために暗く見える. 然し GH と ACTH との同時注射は ACTH 単独投与よりあ小さ い脂肪顆粒を增加させていることは明かである。下瑟体摘出時に於ける粗大脂肪顆粒や瘾合した不正形の大 きな脂肪顆粒林く，何礼む均等に小さい脂肪顆粒である。このことはやはり活発なる活動を物語るもので はあるが，ストレス曝露時に見られた如き急激なホルモン合成と放出とな必要とするわけではなく，合成さ れてホルモン物斦を脂肪顆粒として胞体内に貯蔵する比輍的安定せる合成能として回復している如く思われ

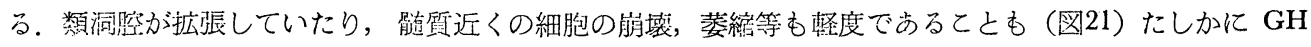
と ACTH の協調的作用が存在するととを示す．随質近くに現すれる結合絽緎の增生も始んどない. 斯くの 如く隄止の垣度は $\mathrm{GH}, \mathrm{ACTH}$ の同時投与が最も強いのである。

\section{考察}

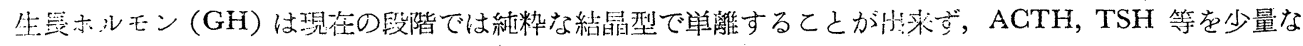
がら含有していると云礼机ている。拣実含回，私が用いた GH は $1 \mathrm{mg}$ 中に 0.01 i.u. の ACTH を含む のである。從つて純粋な GH の副婜に対する作用をたしかするととには消幾多の因難が残されている. GH 结约若動物の生長促進作用のあることは勿論であるが，成熟動物之雖も，生理的條件の範团で各細胞の 增殖と大い関係がある。特汇内分泌腺に於いては絶えず細胞の新生之退化とが繰返壳されるわけであるか ら (吉村 1955 参照)，GH 分此の現象に直接間接関係していることは想像活来るととである。 まして副 留皮質では被膜で新生されだ細胞か除々に深層に移動し，網状層で細胞念死隇する一定の生活史を営むてと 在推定する細胞移動学説（エスカレータ一説）あある位であるから，GH 分何等かの関係を有するととが相

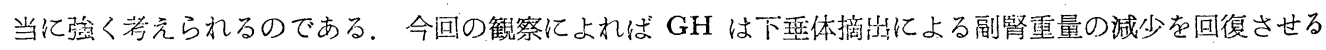
ことぶ出来ず，組織学的にも球状圈之移行層との增大を回復させるととは山出来ず，又 ACTH の如く束状層 細胞行可染性顆粒を增加させて，恰もストレスに懪された動物のこれに近づかせることもない，摘出時と同 様細胞内には脂肪顆粒が多いのであり，放出は促進されない。

次に ACTH には下蕉体摘出ラットの副敊重量を回復させる力とアスコルビン酸の低下を回復させる力 とが区別され，両者は完全に異質的であることが報告された(Stack-Dunne 1953, Stack-Dunne とYoung 1951). Dixon 等 (1951) む ACTH に ascorbic acid depleting factor と weight factor との 2 つを区別した. 彼 
等によれば weight factor は下垂体摘出後 1 2 週間を経てから 3 日間注射するととによつて効力が判定 される. 而あその時アスコルビン酸の activity は極めて低いのである. この weight factor が如何なるす のであるか, 或は GH と関係があるか否かは確かなととはわからない. ACTH (3mg) を正常ラットに注 射すれ洨，被櫒細胞加ら皮質細胞への転化が促進され球状層に於ける milosis を起させるととを Baker (1952）は指摘しているが，之等は何れも weight factor 之関係がある. Young (1951) は weight factor が GH このあのではないかと疑つている程である. Stcck-Dunne と Young (1951) によれば牛の下瑟体粗製 エキス $180 \mathrm{mg}$ ，純化された GH 22mg は Soyers の test には弱く而も副腎重量は 9mg から 12〜15mg まで肥大させるととが出来たと報告した。

今回の $2.5 \mathrm{mg} /$ 日 5〜7 日間の注射による ACTH 実験ではやはり重量増加には成功しなかつたし， 凤 $\mathrm{GH}+\mathrm{ACTH}$ であやはり顕著な回復はみられなかつた。 このととは注射量及び投与方法に欠陷があり，と くに depo-form の ACTH の注射を必要とし, ての点あらためて実験を追加する必要があると思う。然し $\mathrm{ACTH}$ 単独投与によつて, 絽織学的にはかなり細胞の活動力は回復し, 密乃個々の細胞の内部構造及び球 状層に関する限りストレスに曝された如き状態になつたのである．細胞の減少と萎縮とは回復させることは 出来ないにあ拘らず，その限られた細胞の分泌サイクルを full に回転している様に思える。 GH + ACTH 同時投与によつて生ずる回復力はやはり最高であり，球状層の縮少，被膜細胞から皮質細胞への転化促進， 束状圓細胞の配列のより見事な修復，束状層細胞に於ける大きさの一定した脂肪顆粒之可染顆粒之の釣合つ た同時的出現等が見られたのであり，乙の点 GH が ACTH の副腎皮質に対する回復作用に協調的に働い ているととを示す原因である.

最後仁私の所見と Lostroh とWoodward（1958）の記載とを比較する。 Lostroh は下垂体摘出13日のマウ

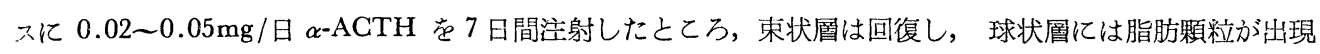
し， $0.1 \mathrm{mg}$ の注射では副腎重量は $100 \%$ 回復したと述べた. GH $0.1 \mathrm{mg}$ の同日数では下垂体摘出群と大 体同じ所見であつたが，GH+ACTH では ACTH 単独よりも副腎重量はよく回復した。即ち対照 $1.9 \pm$ $0.1 \mathrm{mg}$ が $\alpha$-ACTH 単独では $4.2 \pm 0.2 \mathrm{mg}, \mathrm{GH}$ 単独では $5.1 \pm 0.2 \mathrm{mg}, \mathrm{ACTH}$ と GH との同時では $7.0 \pm 0.3 \mathrm{mg}$ であつた。 一方 Sudan Black B の染色の上でむ球状首及び束状㞗のリポイド量は $\alpha$-ACTH 上 りも $\mathrm{GH}+\alpha-\mathrm{ACTH}$ が著明であり, GH 単独は殆ど院性であり, 即ち $\mathrm{GH}$ は代謝面では促進させせない とを示している。 Lostroh の報告は以上の通にである。乙れ等の知見は私の得た組織学的所見とは全面的に 一致しない．然し変化の方向は一致している．副督重量の回復は私の実験では全く見られなかつたことは前 化言及した通りである，然し $\mathrm{GH}+\mathrm{ACTH}$ の回復に対する㙝調的作用は彼等と同じように，之を認める立 埸に立たざるを得ない。

今回の実験には幾多の不借があり, てれを補う実験を目下続行中であり, 追つて発表する予定である.

総括

Wistar 系雄性成熟ラット（生後60９0日）の下瑟体を摘出し，その後 ACTH と GH の単独及び同時

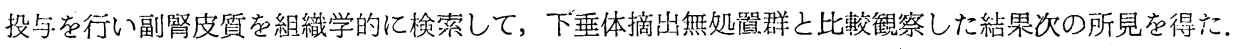

1）副緊の重量变化は実験例数の僅少，動物の個体差もから品合つて複雑な数做を示し確定的な結論には 達しないが，今回の測量に從えば下垂体摘出後明かに副腎重量の減少が起るが，ACTH $(2.5 \mathrm{mg} /$ 日， 7, 10 日）のいわゆる maintenance test を行つても殆ど有意の回復を示さない. GH ( $2 \mathrm{mg} /$ 日，7日）の注射む 同様である. 又術後 6 日目より ACTH 同量 5 日間, ACTH 及び GH 5 日間の注射を行い repair test を企 てたが，乙叹有意つ回復力を示さない，従つて副筱重量に関しては ACTH，GH はての投与方式による 限り無效である様に考えられる。

2) 然しながら組織学的には一定の回復力がある. 対照群では下垂体摘出 7 日後に球状首は部分的に屯幅 を增し，多少とも束状配別の傾向を示す，脂肪顆粒を豊富に含有する．移行層は幅を增し，核の密篹帯とな り，若千とむ肥大して来る，束狱層は細胞の配列は乱れ，細胞索は細く不完全で互に吻合し，多少とむ萎縮 
性となり，胞体内には脂肪顆粒が豊富に存在するが可染性顆粒は少ない傾问がある，髄質近くでは細胞は扁 平となり，周辺に結合織の増生が見られる。下垂体摘出10日後は 7 日後の所見と略々等しく，唯徐々に上記 症状が増強される。

3）下垂体を摘出後 ACTH を 7 10日間投与すれば，皮質そのものの厚さは回復する様な所見はなか

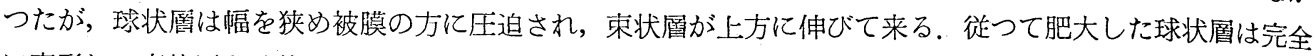
に変形して束状圓と球状層とが一続さである，移行層は消失している．皮質表層では脂肪顆粒が乏しく，可 染性顆粒（鉄へマトキシリン）が豊富である. 束状層細胞自身の萎縮及び配列の乱れは ACTHによつてす 回復されないが，大きな脂肪顆粒は消失し可染性顆粒が増加する．即ち内部構造上の改善がある，下垂体绱 嵌によつて生じた随質近くの結合織の増生は ACTH によつて完全に迄近く消失する. 以上の如く ACTH 投与によつて或る程度の回復は望める. 少くともストレス曝露時の所見と似て来る.

4) ACTH の repair test でもやはり maintenance test と大体同じ回復力を示す. 勿論主として細胞 配列及び代謝面に関係する如き内部構造の変化であつて，細胞の大きさ及び増殖性変化には影響が殆どな (1)

5）下重体摘出後 GH を7日間連続投与した場合（maintenance test）では，下垂体摘岀の症状は余り 回復しない. 然し下垂体摘出群と全く同じ所見ではなく，束状に配列した球状層では特に被膜の近くで可染 性顆粒が密集する傾向が強く，球状層の深層で脂肪顆粒が䇺富である．又下垂体摘出によつて㭪近質の近くに 見られた結合織の増生は ACTH と同じく GH でも消失させることが出来た。 従つて用いた GH 単独で

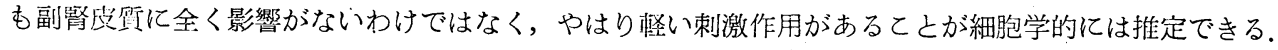

6) 下量体摘出後 $\mathrm{ACTH}$ 及び GH を 5 日間に方たり薑続的に同時に投与した場合 (repair test) では, 著しい摘山症状の改善が認められた。 即ち球状層の肥大は更に強力に阻止される. ACTH 単独投与と同椂 束状層が被䑏にまで達し，そこでは可染性顆䊉が充满している，又正常ラットに見られる様な㭃若な糸球が

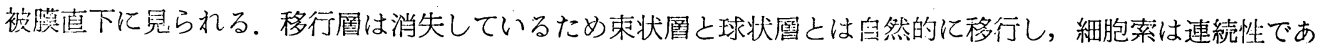
る. 束状尿細胞の配列，萎縮はやはり ACTH 単独と同様に充分に回徣しない. 然し可染性顆粒の増加之共 に小さい大きさの一定した脂肪顆粒が増加していることは同時誌:特徽である。比䧶的安定した代謝面で

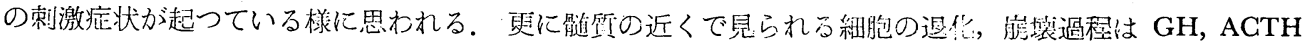
同時投与により最も效界的に阻止されており，その点でも協讙的俳用ゔあることぶ推定される.

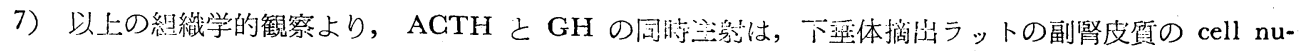
mber, cell volume 等の㳹少を充分に隄止できないけれじも，細胞配列，内部構造の上では最も效果的な協 調的改善をもたらし，恐らく与えられた細胞の條件の下で最大のホルモン分泌を澓行するととが考えられ る.

終りにのぞみ，御想篤なる御指導を賜わつた吉村不二夫教授に感謝致します。.

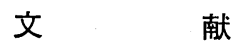

1) Baker, B.L. : Recent Prog. in Hormone Research $7: 331,1952 . \quad 2$ 2) Bois, P., H. Salye : J. Endocrinol. $15: 173,1957 . \quad$ 3) Deane, H.W., J.H. Shew and R.O. Greep : Endocrinol. $43: 133,1948$.

4) Dixon, H.B., F.S. Moore, M. Stack-Dunne and F.G. Young: Nature $168: 1044,1948 . \quad$ 5) Giroud, C. J.P., J. Stackenko and E.H. Venning : Proc. Soc. Exp. Biol. Med. $92: 154,1956$.

6) Holzbaver, M.,

M. Vogt : J. Physiol. 138 : 449, 1957.

7) Lever, J.D. : Endocrinol. $58:$ 163, 1956.

8) Lostroh,

A.J. : Proc. Soc. Exp. Biol. Med. $97: 828,1958 . \quad 9)$ Lostroh, A.J., P. Woodward : Endocrinol. 62 : $498,1959$.

10) Maclean, J.P., M.B. Lipsett, M.C. Li,

C.D. West and O.H. Pearson : J. Clin. Endocrinol. $17: 346,1957$.

11) Muller, A.F., A.M. Riondel and E.L. Manning : Lancet $271: 6951,1021,1956$. 
12) Kovacs, K., B.M. Kovacs, G.S. Kovacs and G. Petri : Naturwissenschaften $44: 241,1957 . \quad 13)$ Nagy, A., A. Olah and S. Karady : Nature $180: 1481,1957 . \quad$ 14) Rosenfeld, G., E. Rosenberg, F. Ungar and R.I. Dorfman : Endocrinol. $58: 255,1956 . \quad 15)$ Sayers, M.A., G. Sayers and L.A: Woodbury: Endocrinol. $42: 379,1948 . \quad 16)$ Selye, H. : Brit. Med. J. $1: 263,1951 . \quad 17)$ Selye, H. : Proc. Soc. Exp. Biol. Med. $76: 510,1950$. 18) Selye, H., H. Stone : On the experimental morphology of the adrenal cortex $1950 . \quad$ 19) Simpson, M.E., H.M. Evan and C.H. Li : Growth $13: 151,1949$. 20) Stack-Dunne, M.P. : Ciba Found. Coll. End. $5: 133,1953 . \quad 21)$ Stack-Dunne, M.P., F.G. Young : Brit. Med. J. 1 : 1386, $1951 . \quad$ 22) Stein, J.D., L.L. Bennett., A.A. Batts and C.H. Li : Am. J. Physiol. $171: 587,1952 . \quad 23)$ Venning, E.H., I. Dyrenfurth, C.J.P. Giroud and J.C. Beck : Metabolism $5: 997$, 1956. 24) Wexler, B.C., A.P. Rinfret, A.C. Griffin and H.L. Richardson : Endocrinol. $56: 120,1955$.

25）横須賀篤：ホルモンと臨床，6:251，1958. 26）横須賀篤：印刷中 (1960） 27) Yoshimura， F. : Endocrinol. Jap. 1:177, 1954. 28) 吉村不二夫 : 内分泌, 2:191，1955. 29）吉村不二夫 : ホルモンと臨床, $7: 95,1959 . \quad 30)$ Young, F.G. : Lancet $2: 1211,1951$.

\section{附図説明}

Fig. 1. Adrenal cortex of a rat, 7 days after hypophysectomy. Cortex is atrophic, and the involution is most pronounced in the fasciculata and reticularis. The connective tissue grows near the medulla. G : Capsule, G : Zona glomerulosa, T : Transitional zone, F : Zona fasciculata, R : Zona reticularis, $M$ : Medulla. Levi. iron-hemat. $\times 100$

Fig. 2. Adrenal cortex of a rat, 7 days after hypophysectomy. The cells of the glomerulosa contain a lot of fat granules. The transitional zone is widened and the boundary between cells is indistinct. The cells appear to be not flat but large polygonal in shape and their dark-shadowy cytoplasm contains a few number of fat granules. G : Capsule, G : Zona glomerulosa, T: Transitional zone, F : Zona fasciculata. Levi. iron-hemat. $\times 400$

Fig. 3. Atrophic adrenal cortex of a rat, 10 days after hypophysectomy. The glomerulosa became broader than 7 days. The cells of the glomerulosa are rich in fat granules too. The involution is advanced in the fasciculata and reticularis. There is seen the degeneration and disintegration of the cells as well as the hyperplasia of the connective tissue. $\mathrm{G}:$ Capsule, $\mathrm{G}:$ Zona glomerulosa, $\mathrm{T}$ : Transitional zone, F : Zona fasciculata, R : Zona reticularis, M : Medulla. Levi. iron-hemat. $\times 100$

Fig. 4. Zona glomerulosa of adrenal cortex of a rat, 10 days after hypophysectomy. The glomerulosa cells contain a number of fat granules, whereas the cells in transitional zone are devoid of them. G : Capsule, G : Zona glomerulosa, $\mathrm{T}:$ Transitional zone, F: Zona fasciculata. Levi. iron-h emat. $\times 400$

Fig. 5. Adrenal cortex of a hypophysectomized rat treated with $2.5 \mathrm{mg} /$ day ACTH for 7 days (maintenance test). The glomerulosa become narrower by the hormone administration. The cells in whole area of cortex are dark on account of the package of stainable granules. G : Capsule, G : Zona glomerulosa, F : Zona fasciculata, R : Zona reticularis, M : Medulla. Levi. iron-hemat. $\times 100$

Fig. 6. Zona glomerulosa of a hypophysectomized rat treated with the same dose of ACTH (maintenance test). The glomerulosa does not show the typical glomeruli, but consists of the cell-strands which contain a majority of stainable granules, in spite of a few fat granules. The transitional zone is no longer present. $\mathrm{C}$ : Capsule, G : Zona glomerulosa, F : Zona fasciculata. Levi. iron-hemat. $\times$ 400

Fig. 7. A hypophysectomized rat treated with $2.5 \mathrm{mg} /$ day ACTH for 10 days (maintenance test).

\section{第35巻 第 12 号}


The glomerulosa become narrower. Its cell-strands extend themselves to the capsule. G: Capsule, G : Zona glomerulosa, $\mathrm{F}$ : Zona fasciculata, $\mathrm{R}$ : Zona reticularis, $\mathrm{M}:$ Medulla. Levi. iron-hemat. $\times$ 100

Fig. 8. A hypophysectomized rat treated with ACTH for 10 days (maintenance test). The cell cords of superficial areas are upwards ended into the capsule, so that it is very difficult to distinguish between the glomerulosa and the fasciculata, presenting the mutual transformation. G: Capsule, G : Zona glomerulosa, F : Zona fasciculata. Levi. iron-hemat. $\times 400$

Fig. 9. The reticularis of a hypophysectomized rat treated with ACTH for 10 days (maintenance test). The many sinusoids are dilated and the connective tissue decrease by the replacement therapy. $\mathrm{F}:$ Zona fasciculata, $\mathrm{R}:$ Zona reticularis, $\mathrm{M}:$ Medulla. Levi. iron-hemat. $\times 400$

Fig. 10. Adrenal cortex of a hypophysectomized rat treated with $2.5 \mathrm{mg} /$ day ACTH' for 5 days from 6th day (repair test). In spite of no restitution of the size of whole cortex, the histological signs of the ablation are sufficiently improved in the zonation and the internal structure of cortical cells beyond the normal level, showing the pattern under the stressful stimuli. $\mathrm{C}$ : Capsule, G : Zona glomerulosa, F : Zona fasciculata, R : Zona reticularis, M : Medulla. Levi. iron-hemat. $\times 100$

Fig. 11. The outer part of adrenal cortex of a hypophysectomized rat treated with ACTH for 5 days after the 6 th day (repair test). The glomerulosa is extraordinarily atrophic, not forming the typical glomeruli, but consisting of the irregularly existing cells which are either independent or in a fused mass. G : Capsule, G : Zona glomerulosa, F : Zona fasciculata. Levi. iron-hemat. $\times 400$

Fig. 12. The inner part of adrenal cortex of hypophysectomized rat treated with ACTH for 5 days after the 6th day (repair test). The cell-stran'ds of the fasciculata are slender and anastomosed. The connective tissue is absent near the medulla, in spite of the dilation of sinusoids in the reticularis. F : Zona fasciculata, R : Zon.a reticularis, M : Medulla. Levi. iron-hemat. $\times 200$

Fig. 13. Adrenal cortex of a hypophysectomized rat treated with $1 \mathrm{mg} /$ day $\mathrm{GH}$ for 7 days (maintenance test). The glomerulosa remains to be hypertrophic by the administration, in which is not present the typical glomeruli, but cell-strands. The transitional zone is a kind of cell layer containing a mass of nuclei. The histological symptoms of the extirpation is not enough swept up by the administration. G : Capsule, G : Zona glomerulosa, $\mathrm{T}:$ Transitional zone, F : Zona fasciculata, R : Zona reticularis, $M:$ Medulla. Levi. iron-hemat. $\times 100$

Fig. 14. The glomerulosa of a hypophysectomized rat treated with GH (maintenance test). The glomerulosa is composed of cell-strands, which contain a number of the stainable granules, however on the contrary in the innermost area of the glomerulosa appear the fat granules. The transitional zone is unable to disappear completely by $\mathrm{GH}$ administration. $\mathrm{G}$ : Capsule, G : Zona glomerulosa, $\mathrm{T}:$ Transitional zone. Levi. iron-hemat. $\times 400$

Fig. 15. The inner part of adrenal cortex of a hypophysectomized rat treated with GH (maintenance test). The atrophic changes in cortical cells and irregular arrangement of cell-strands induced by the hypophysectomy are not improved by GH administration, whereas the connective tissue enclosing the medulla is fairly deprived by the hormone therapy. F : Zona fasciculata, $\mathrm{R}$ : Zona reticularis, M : Medulla. Levi. iron-hemat. $\times 200$

Fig. 16. The outer part of adrenal cortex of a hypophysectomized rat treated with $2.5 \mathrm{mg} / \mathrm{day}$ ACTH and $2 \mathrm{mg}$ /day GH in combination for 5 days after the 6 th day (repair test). The glomerulosa consists of cell-strands which are the elongation of the fasciculata, both of which is packed with the stainable granules instead of fat droplets, presumably representing the acceleration in cortical func- 
伊東 論 文附 図（その 1)
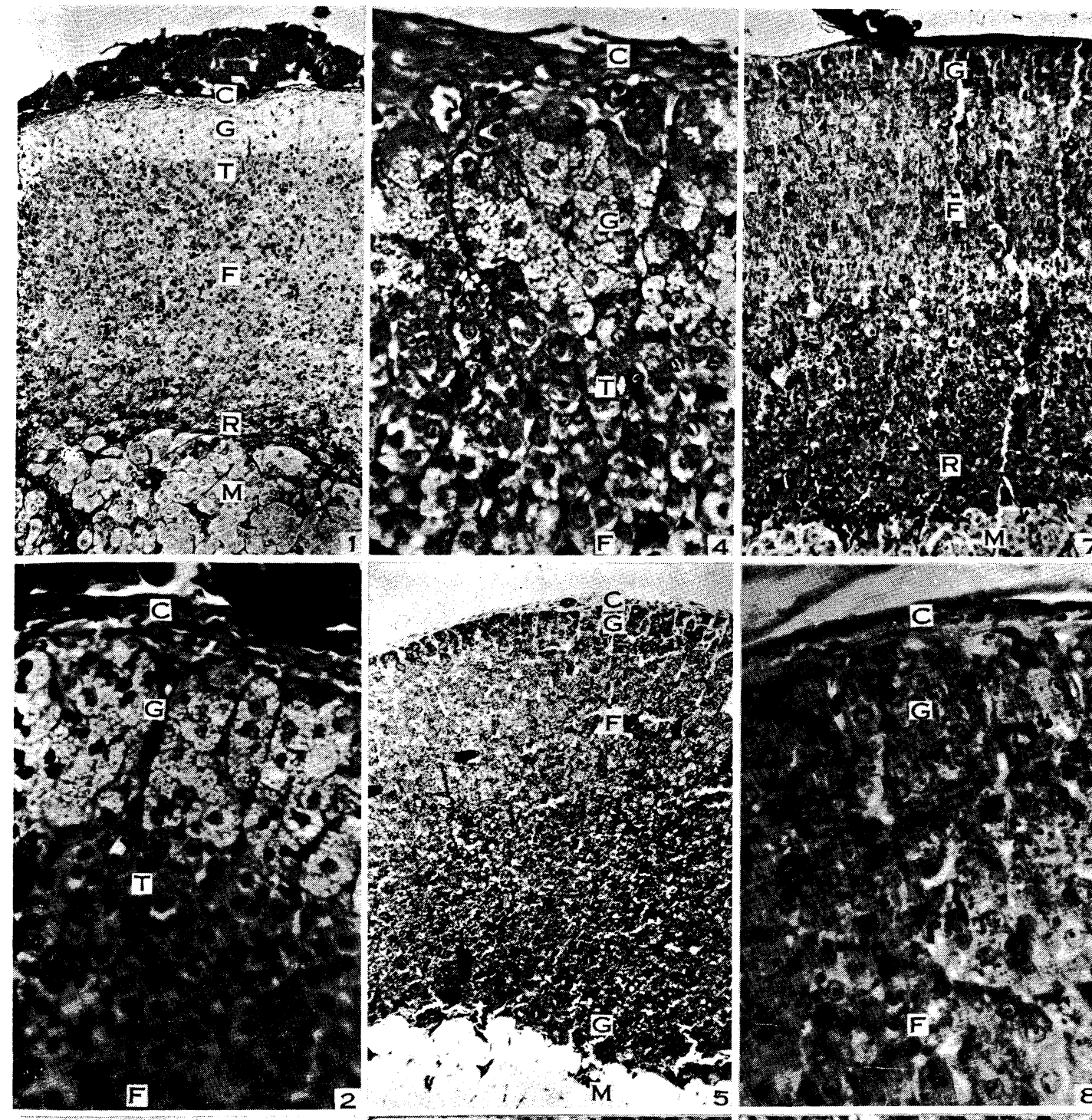

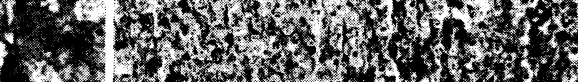

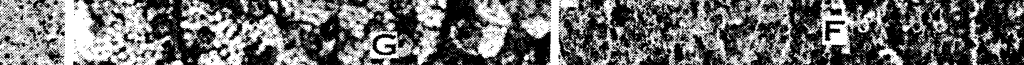

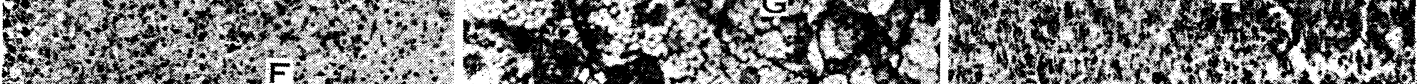

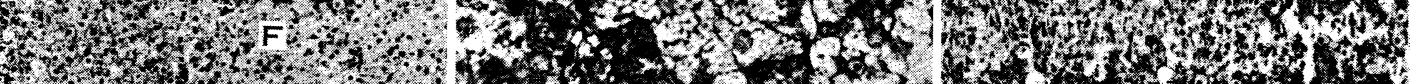

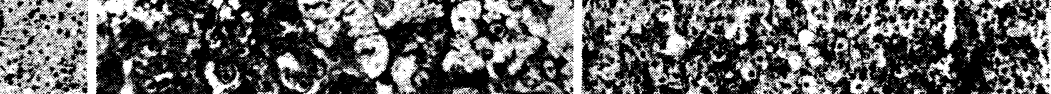

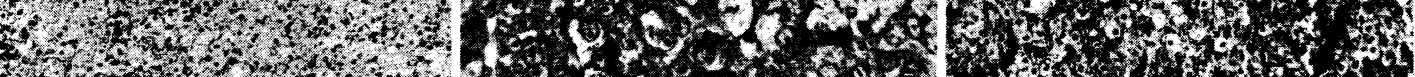

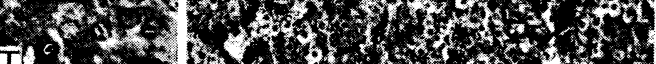

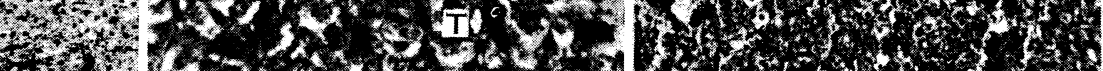

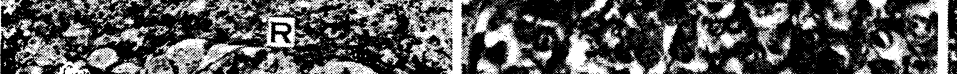

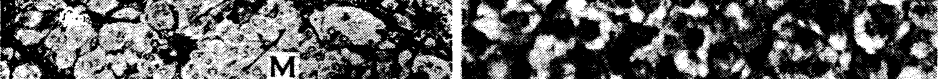

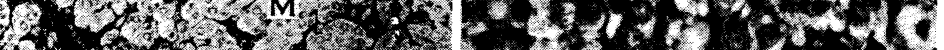

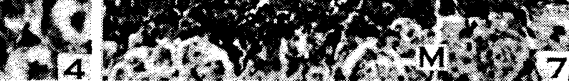

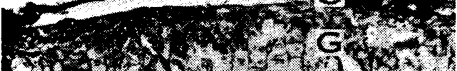

H.

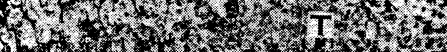

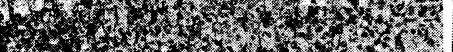

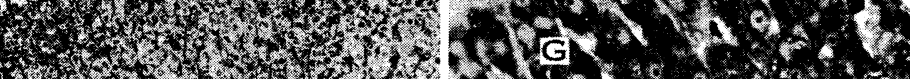

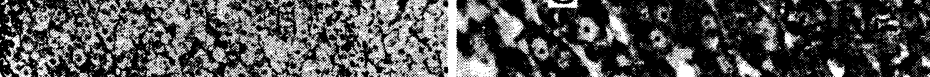

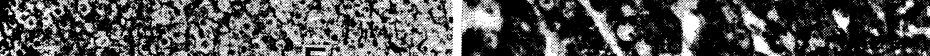

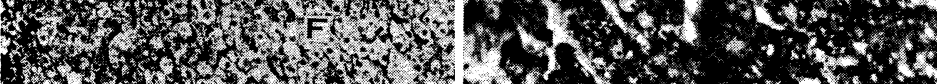

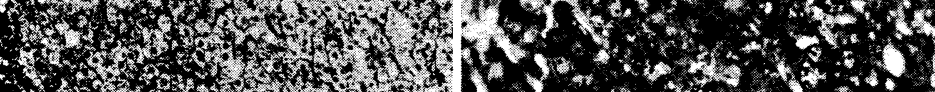

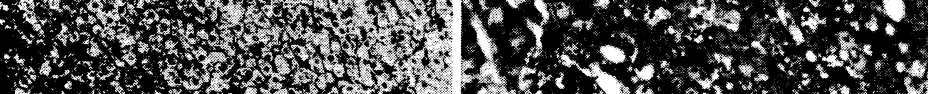

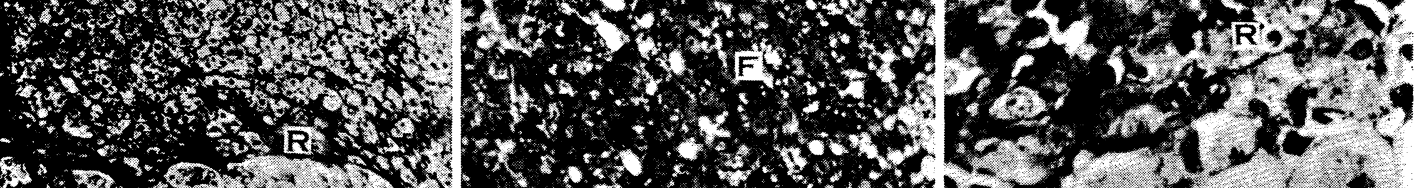

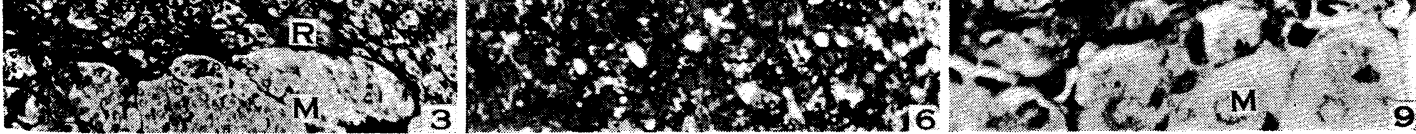



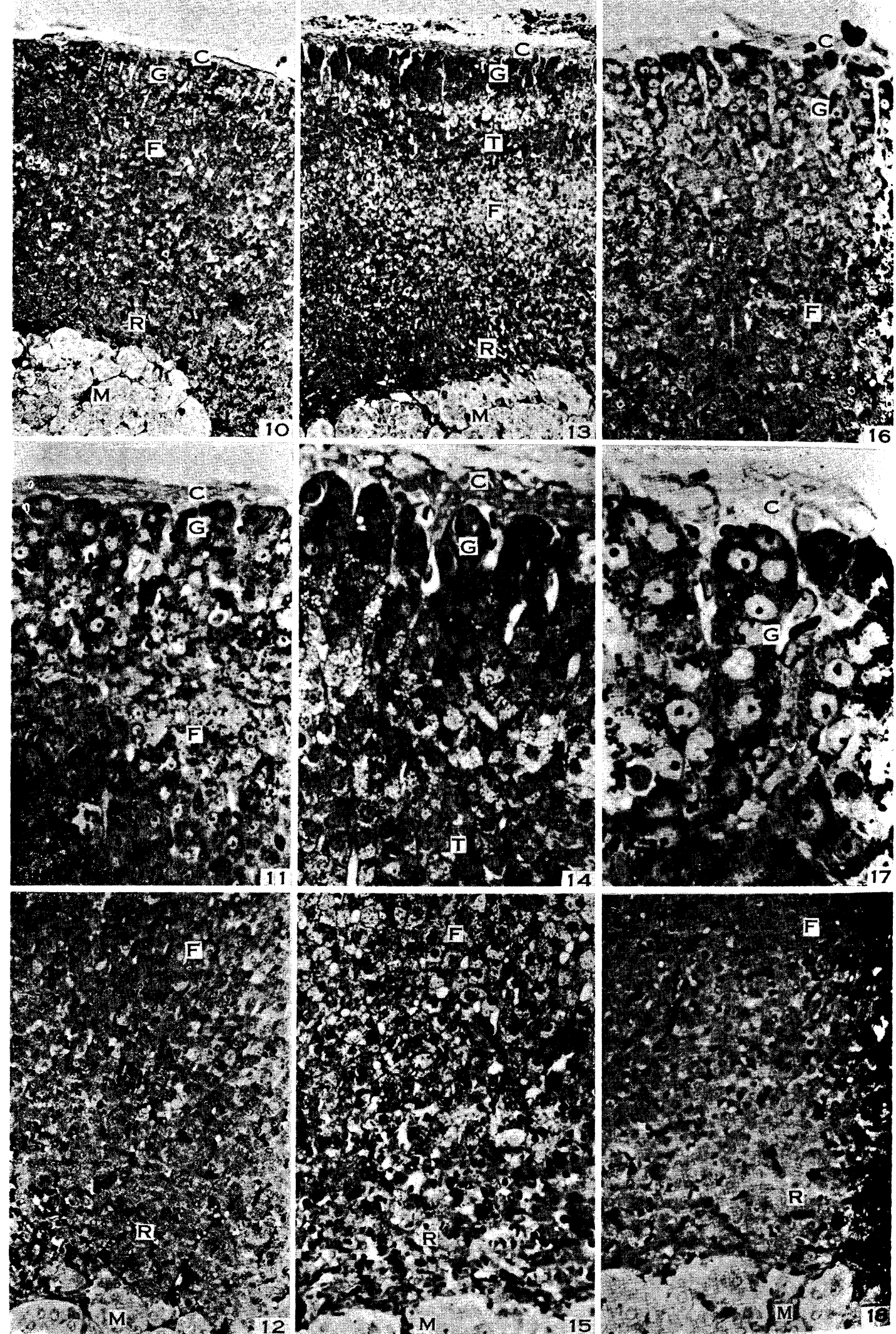
tion. G : Capsule, G : Zona glomerulosa, F : Zona fasciculata. Levi. iron-hemat. $\times 200$

Fig. 17. High magnification of the glomerulosa of a hypophsectomized rat treated with ACTH and GH in combination (repair test). The cell-strands are penetrated upwards through the glomerulosa, and contain lots of stainable granules, in particular most abundantly in the upermost area. C : Capsule, G : Zona glomerulosa, Levi. iron-hemat. $\times 900$

Fig. 18. The inner part of adrenal cortex of a hypophysectomized rat with ACTH and GH in combination (repair test). The picture almost corresponds to the pattern of normal untreated rats and the connective tissue surrounding the medulla disappears by the simultaneous administration. F : Zona fasciculata, $\mathrm{R}:$ Zona reticularis, $\mathrm{M}:$ Medulla. Levi. iron-hemat. $\times 200$ 